\title{
Research on the Establishment of Greenhouse Gas Emissions Key Enterprises Statistical Index System and Reporting system
}

\author{
Jun Song ${ }^{1}$, Kebai Wang ${ }^{2}$ \\ ${ }^{1}$ Hainan Research Institute of Economic Sustainable Development, Haikou Hainan, 570203, China \\ ${ }^{2}$ Statistical Society, Hainan Federation of Social Science Circles, Haikou Hainan, 570203, China
}

Key words: Greenhouse gas, Statistics, Dynamic basic variables.

\begin{abstract}
In our country's research and activities carried out for the climate change from place to place at present, because state and local statistical system on climate change is still in constant research and improvement, carrying out activities and research lacks reference and guidance from authoritative greenhouse gas emissions data statistics. Based on the national clean development mechanism fund(CDMF) research project "Hainan cope with climatic change accounting and statistical power system research", this article extracts various dynamic basis variables in calculation methods, establish greenhouse gas emissions statistics index system around demand of all climate change activities and design the system of statistics reports on climate change for the reference of our country's activities and research work to cope with climate change according to the greenhouse gas emissions accounting standards in key enterprises issued by our country.
\end{abstract}

\section{Introduction}

From 70-80s of the 20th century the international society's realizing the seriousness and urgency of the issue of climate change, the United Nations Environment Programme(UNEP) and the world meteorological organization (WMO) established the intergovernmental panel on climate change in November 1988, brought together hundreds of first-class experts in the field of study on warming world to evaluate the potential environmental and socio-economic impact of human activities on climate change. Until April 22, 2016, the climate change agreement signed in New York- Paris Agreement, a growing number of countries (more than 170 countries) gathered in the United Nations to participate in the activities in the global response to climate change.

With the rapid development of China's economy and society, the total energy consumption and greenhouse gas emissions increased rapidly. Demands and expectations from international parties for our country to control greenhouse gas emissions and bear bigger international responsibilities are rising constantly. In this process, the key of whether we can point out problems and find out the contradiction between our greenhouse gas emissions and the rapid economic and social development, whether we can achieve our commitment to greenhouse gas emissions in the world by formulation and implementation of policy and system for controlling gas emission, improvement of production technology as well as improvement of greenhouse gas emissions monitoring technology,lies at whether the scientificity of statistical index system and reporting system establishment for coping with climate change can get guarantee, especially the establishment of statistics index system and the reporting system in the field of industry is the top priority.

\section{The system of controlling greenhouse gas emissions in the field of current industry of our country administrative management system}

Taking Hainan province as an example, the government control system for the work of dealing with climate change is as follows: 


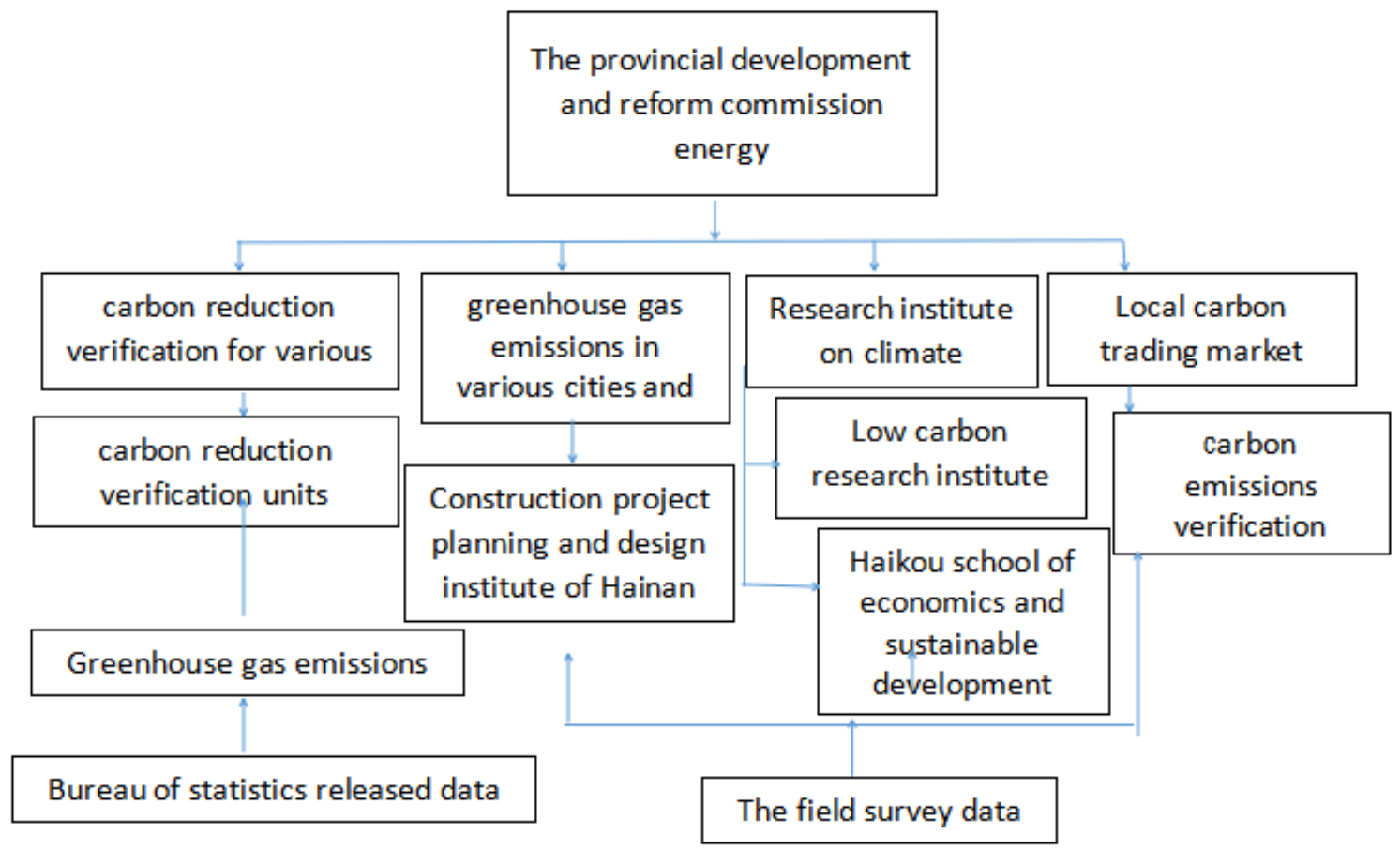

The administrative management system shows that except for the assessment of carbon reduction dominated by the government adopts the statistical data released by statistical bureau for coping with climate change, the formulation of greenhouse gas emissions lists in various cities and counties, activity research on climate change and local carbon emissions verification all adopt field survey data.

\section{The current key enterprises of greenhouse gases emissions statistical index system in our country [1]}

Table 1

\begin{tabular}{|c|c|c|c|c|}
\hline Classification & Index & Name of statement & Material source & $\begin{array}{c}\text { Department in } \\
\text { charge }\end{array}$ \\
\hline \multirow{5}{*}{ 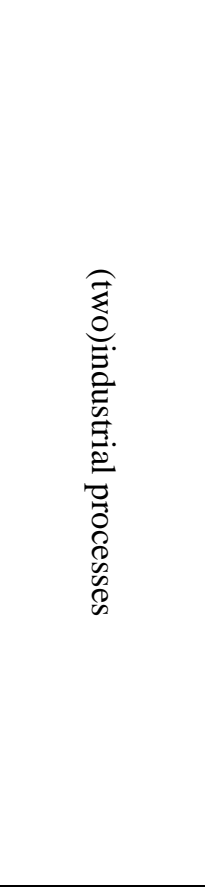 } & $\begin{array}{l}\text { 1.The principal source } \\
\text { of greenhouse gas } \\
\text { emissions products } \\
\text { production in industrial } \\
\text { enterprises above } \\
\text { designated size } \\
\end{array}$ & $\begin{array}{l}\text { 19.The principal } \\
\text { source of greenhouse } \\
\text { gas emissions products } \\
\text { production in industrial } \\
\text { enterprises above } \\
\text { designated size }\end{array}$ & $\begin{array}{l}\text { Industrial statistics statement } \\
\text { system(table B104-3) }\end{array}$ & $\begin{array}{l}\text { State Statistics } \\
\text { Bureau }\end{array}$ \\
\hline & $\begin{array}{l}\text { 2.raw materials } \\
\text { consumption related to } \\
\text { greenhouse gas } \\
\text { emissions in the } \\
\text { process of iron and } \\
\text { steel production } \\
\end{array}$ & $\begin{array}{l}\text { 20.ron and steel } \\
\text { enterprises greenhouse } \\
\text { gases related situation }\end{array}$ & $\begin{array}{l}\text { Department statistics statement } \\
\text { system on climate change } \\
\text { (trial)(table P708) }\end{array}$ & $\begin{array}{l}\text { China Iron and } \\
\text { Steel } \\
\text { Association }\end{array}$ \\
\hline & $\begin{array}{l}\text { 3.including import and } \\
\text { export amount of } \\
\text { fluoride gas }\end{array}$ & $\begin{array}{l}\text { 21.including import } \\
\text { and export amount of } \\
\text { fluoride gas }\end{array}$ & $\begin{array}{c}\text { Department statistics statement } \\
\text { system on climate change } \\
\text { (trial)(table P709) }\end{array}$ & $\begin{array}{l}\text { Ministry of } \\
\text { Environmental } \\
\text { Protection } \\
\end{array}$ \\
\hline & $\begin{array}{l}\text { 4.including production } \\
\text { and handling amount of } \\
\text { fluoride gas }\end{array}$ & $\begin{array}{c}\text { 22.including } \\
\text { production and } \\
\text { handling amount of } \\
\text { fluoride gas }\end{array}$ & $\begin{array}{l}\text { Department statistics statement } \\
\text { system on climate change } \\
\text { (trial)(tableP710) }\end{array}$ & $\begin{array}{l}\text { the same as } \\
\text { above }\end{array}$ \\
\hline & $\begin{array}{l}\text { 5.including using } \\
\text { amount of fluoride gas }\end{array}$ & $\begin{array}{l}\text { 23.including using } \\
\text { amount of fluoride gas }\end{array}$ & $\begin{array}{c}\text { Department statistics statement } \\
\text { system on climate change } \\
\text { (trial)(table P711) }\end{array}$ & $\begin{array}{l}\text { the same as } \\
\text { above }\end{array}$ \\
\hline
\end{tabular}


It can be seen from table 1 that the covering content of statistical indicators of greenhouse gas emissions in industrial production process is very limited. And actually in the process of China's industrial development, the key units of greenhouse gas emissions are involved in many fields, including dozens of areas such as electricity, oil, metals, ceramics, coal, and so on. In different areas, in the future there will be more and more enterprises emission greenhouse gas involved in the assessment and carbon trading market.

\section{Our country's industry report system for coping with climate change[2]}

Table 2: industrial enterprises' main greenhouse gas emissions source products production statistics

\begin{tabular}{|c|c|c|c|}
\hline Product name & $\begin{array}{c}\text { unit of } \\
\text { measurement }\end{array}$ & code & Output \\
\hline Party A & Party B & Party C & 1 \\
\hline $\begin{array}{c}\text { portland cement clinker } \\
\text { Among: Cement clinker kiln outside the } \\
\text { decomposition kiln } \\
\text { Cement } \\
\text { lime } \\
\text { Steel } \\
\text { calcium carbide( } 300 \mathrm{~L} / \mathrm{kg} \text { for account) } \\
\text { adipic acid } \\
\text { nitric acid } \\
\text { Aluminium } \\
\text { Mg }\end{array}$ & $\begin{array}{l}\text { Ten thousand tons } \\
\text { Ten thousand tons } \\
\text { Ten thousand tons } \\
\text { Ten thousand tons } \\
\text { Ten thousand tons } \\
\text { Ten thousand tons } \\
\text { Ten thousand tons } \\
\text { Ten thousand tons } \\
\text { Ten thousand tons } \\
\text { Ten thousand tons } \\
\text { Ten thousand tons }\end{array}$ & $\begin{array}{l}01 \\
02 \\
03 \\
04 \\
05 \\
06 \\
07 \\
08 \\
09 \\
10\end{array}$ & \\
\hline
\end{tabular}

\section{The domestic research status}

At present, it is rare to see the domestic literature engaged in statistical research on climate change with most concentrated in the last three years. For example, Tian Xinru (2015) interpreted the statistic related international and domestic theory coping with the climate change and pur forward ideas on system construction and implementation security; Huang Qiang (2016) analyzed the Guangxi statistical indicator system for coping with climate change and user demand gap and put forward suggestions. In addition to the above literature, literature targetedly research on coping with climate change statistical problem is not much. This article does not carry out the interpretation from the aspects of theory and put forward suggestions but extracts the dynamic basis variables in accounting standards system directly according to the demand of accounting requirements, constructs statistical indicators and statistical reporting system.

\section{The index system extraction}

At present, the national development and reform commission (NDRC) addressing climate change law office department policy section launched greenhouse gas emissions accounting method and report guidelines in 24 industries(trial implementation) which put forward technical standards for greenhouse gas emissions accounting in 24 industries. At the same time, greenhouse gas emissions listing, assessment of carbon reduction and quota for approval for carbon units participating in carbon trading in local governments need to refer to this. In order to better serve the demand party by providing more timely, accurate, and dynamic data of greenhouse gas emissions, combined with climate change activities' carring out and the corresponding research, the statistics department at all levels are in urgent need of a set of standard, unified statistical report system on climate change. The following is extracting the dynamic variables based on emissions accounting method, establishing index system for greenhouse gas emissions to provide basis for formulating system of statistical report for coping with climate change. 
Table 3: Industry area key enterprises greenhouse gas emissions emissions accounting dynamic basic variable extraction table

\begin{tabular}{|c|c|c|c|}
\hline & $\begin{array}{c}\text { type of } \\
\text { enterprise }\end{array}$ & Emissions accounting methods & $\begin{array}{c}\text { Emissions accounting dynamic basic } \\
\text { variables }\end{array}$ \\
\hline 01 & $\begin{array}{l}\text { generate } \\
\text { electricity }\end{array}$ & $\mathrm{E}=\mathrm{E}$ 燃烧 $+\mathrm{E}$ 脱硫 $+\mathrm{E}$ 电 [3] & FCi, CALk, AD电[3] \\
\hline 02 & Grids & $\mathrm{E}=\mathrm{ESF} 6+\mathrm{E}$ 网损[4] & $\begin{array}{l}\text { REC容量, REC回收, REP容量, REP } \\
\text { 容量, EL上网,EL输入,EL输出,EL售出 } \\
{[4]} \\
{[4]}\end{array}$ \\
\hline 03 & $\begin{array}{c}\text { Steel } \\
\text { production }\end{array}$ & $\begin{array}{c}\mathrm{E}=\mathrm{E} \text { 燃烧 }+\mathrm{E} \text { 过程 }+\mathrm{E} \text { 电和热 }-\mathrm{R} \text { 固碳 } \\
{[5]}\end{array}$ & $\mathrm{FCi}, \mathrm{P}$ 溶剂, $\mathrm{P}$ 电极, $\mathrm{M}$ 原料[5] \\
\hline 04 & $\begin{array}{l}\text { chemical } \\
\text { industry } \\
\text { production }\end{array}$ & $\begin{array}{c}\text { EGHG=ECO2-燃烧+EGHG-过程 } \\
-\mathrm{RCO} 2-\text { 回收+ECO2-净电+ECO2- } \\
\text { 净热[6] }\end{array}$ & ADp, ADr, ADw, AD硝酸[6] \\
\hline 05 & $\begin{array}{l}\text { electrolytic } \\
\text { aluminium } \\
\text { production }\end{array}$ & $\begin{array}{c}\mathrm{E}=\mathrm{E} \text { 燃烧+E原材料+E过程+E电和 } \\
\text { 热[7] }\end{array}$ & $\begin{array}{c}\text { FC化石净消耗量, } \mathrm{p}, \mathrm{l}, \mathrm{AD} \text { 电力, } \mathrm{AD} \\
\text { 热力, [7] }\end{array}$ \\
\hline 06 & $\begin{array}{l}\text { Magnesium } \\
\text { smelting } \\
\text { production }\end{array}$ & $\begin{array}{c}\mathrm{E}=\mathrm{E} \text { 燃烧+E原材料+E过程+E电和 } \\
\text { 热[8] }\end{array}$ & $\begin{array}{c}\mathrm{FC} \text { 化石净消耗量, } \mathrm{S}, \mathrm{D}, \mathrm{AD} \text { 电力, } \mathrm{AD} \\
\text { 热力, [8] }\end{array}$ \\
\hline 07 & $\begin{array}{l}\text { flat glass } \\
\text { processing }\end{array}$ & $E=E$ 燃烧 $+E$ 原材料 $+E$ 过程 [9] & $\begin{array}{c}\text { FC化石净消耗量, } \mathrm{Qc}, \mathrm{Mi}, \mathrm{AD} \text { 电力, } \\
\mathrm{AD} \text { 热力, [9] }\end{array}$ \\
\hline 08 & $\begin{array}{c}\text { cement } \\
\text { manufacture }\end{array}$ & $\mathrm{E}=\mathrm{E}$ 燃烧 $+\mathrm{E}$ 过程 $+\mathrm{E}$ 电和热 [10] & $\begin{array}{l}\text { Qi, Qckd, Qbpd, FR1, FR10, FR2, } \\
\text { FR20, Q生料, AD电力, } \mathrm{AD} \text { 热力, }[10]\end{array}$ \\
\hline 09 & $\begin{array}{l}\text { ceramic } \\
\text { production }\end{array}$ & $\mathrm{E}=\mathrm{E}$ 燃烧 $+\mathrm{E}$ 工业 $+\mathrm{E}$ 电力 $[11]$ & $\begin{array}{l}\text { Q燃料, 购入, } \mathrm{Q} \text { 燃料, 期初, } \mathrm{Q} \text { 燃料, 期末, } \\
\mathrm{Q} \text { 燃料,外销, } \mathrm{Q} \text { 原料, 购入, } \mathrm{Q} \text { 原料, 期初, } \\
\mathrm{Q} \text { 原料, 期末, } \mathrm{Q} \text { 原料,外销, Q电量,外购, } \\
\mathrm{Q} \text { 电量,输出, [11] }\end{array}$ \\
\hline 10 & aviation & $E=E$ 燃烧 $+E$ 电和热 [12] & $\begin{array}{c}\mathrm{FC} \text { 化石, } \mathrm{i}, \mathrm{FC} \text { 生物质混合, } \mathrm{j}, \mathrm{AD} \text { 电力, } \\
\mathrm{AD} \text { 热力, [12] }\end{array}$ \\
\hline 11 & $\begin{array}{l}\text { Independent } \\
\text { coking }\end{array}$ & 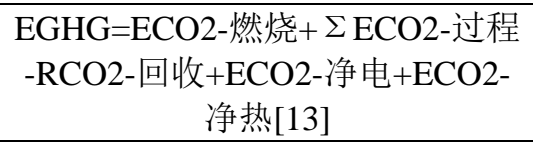 & $\mathrm{ADi}, \mathrm{PMr}, \mathrm{COK}[13]$ \\
\hline 12 & $\begin{array}{l}\text { Coal } \\
\text { production }\end{array}$ & $\begin{aligned} \mathrm{E}= & \mathrm{ECO} 2-\text { 燃烧+ECO2-火炬+ECH4- } \\
& \text { 逃逸 } \times \text { GWPCH4+ECO2-逃逸 } \\
& +\mathrm{ECO} 2-\text { 净电+ECO2-净热 }[14]\end{aligned}$ & $\begin{array}{c}\text { ADij, Q瓦斯-火炬，Q瓦斯-排放，Q瓦 } \\
\text { 斯-利用，Q瓦斯-抽放，QCO2-排放， } \\
\text { QCO2-利用，QCO2-抽放，AD原煤-露 } \\
\text { 天， [14] }\end{array}$ \\
\hline 13 & $\begin{array}{l}\text { petrochemical } \\
\text { engineering }\end{array}$ & $\begin{array}{c}\text { EGHG=ECO2-燃烧+ECO2-火炬 } \\
+ \text { ECO2-过程-RCO2-回收+ECO2- } \\
\text { 净电+ECO2-净热[15] }\end{array}$ & $\begin{array}{c}\text { ADij, Q正常火炬, GF事故, j, T事 } \\
\text { 故,j, AD电力, } A D \text { 热力, Q外供, Q自 } \\
\text { 用 }[15]\end{array}$ \\
\hline 14 & $\begin{array}{l}\text { oil and gas } \\
\text { producing }\end{array}$ & $\begin{array}{c}\text { EGHG=ECO2-燃烧+ECO2-火炬 } \\
\sum_{+s} \text { (EGHG-工艺+EGHG-逃 } \\
\text { 逸)s-RCH4-回收X } \\
\text { GWPCH4-RCO2-回收+ECO2-净电 } \\
\text { +ECO2-净热[16] }\end{array}$ & $\begin{array}{l}\text { ADij, Q正常火炬, GF事故, j, T事 } \\
\text { 故,j, Qk, Hk, Numoil,j, Numgas,j, } \\
\text { Qgas, Qin,k, Qout,k, Qre, AD电力, } \\
\text { AD热力, Maw, Mast[16] }\end{array}$ \\
\hline
\end{tabular}

\section{Statistic statement preparation on climate change}

According to the index system of emissions greenhouse gas emissions above, combined with the national statistics unified format requirements, 14 kind of corporate greenhouse gas emissions based data statistical statements are established. The enterprises include manufacturing enterprises such as power generation, power grids, civil aviation, steel, chemical industry, electrolytic aluminum and 
magnesium smelting, cement, ceramics, glass, petroleum and gas, petrochemical industry, the independent coking, coal etc. Power generation company greenhouse gas emissions basic data statistics statement(table 4 is as follows) is an example for other 13 kind of statistical statements.

Table 4:1. The power generation company greenhouse gas emissions basic data statistics statement

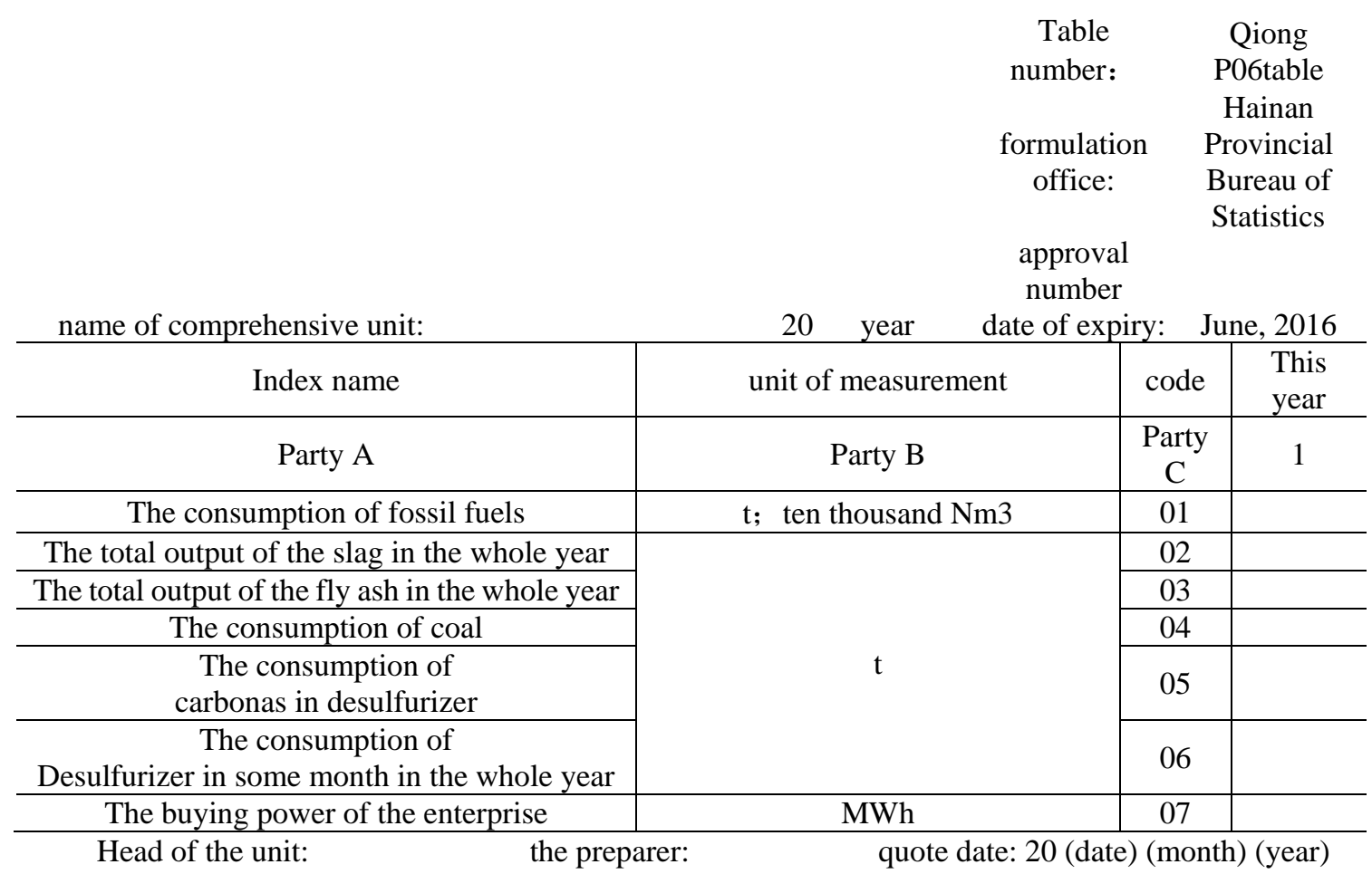

Description: 1 . This form shall be submitted by the responsibility of the Hainan power grid companies ; 2 . The statistical range: thermal power enterprise with the capacity of $6000 \mathrm{kw}$ or more; 3. Submitting time: the next year on March 31.

\section{Conclusion}

To sum up, the research of this article is based on the research of national clean development mechanism fund(CDMF). Around he assessment of carbon reduction, formulation of greenhouse gas emissions listing, carbon trading verification and activities demand coping with climate change, combined with 14 kind of key enterprises greenhouse gas emissions accounting standards, the article extracts the emission statistic index system and formulates system of statistical report coping with climate change hoping this set of system of statistical report and research methods and paths can provide some thoughts reference and work reference for government statisticians and researchers.

\section{Acknowledgement}

This article is the national clean development mechanism fund(CDMF) granted program, name: "Hainan province cope with climate change statistical accounting system research and capacity building"(project number: 2013112))

\section{References}

[1] Wang Xing, Xu Fei, Zhao Youcai. The plot development mechanism development and methodological guide, Chemical industry press. Beijing. 2012.9 .

[2] Source: from the "industrial production gross output and main " (table B204-1) and "the main product output below the scale"(B306 table)in industrial statistics system. 
[3] The national development and reform commission on climate change policy law office. China power generation company greenhouse gases emissions accounting methods and reporting guidelines (trial) , Beijing: 2015-3-27.

[4] The national development and reform commission on climate change policy law office. China electrical network enterprises greenhouse gases emissions accounting methods and reporting guidelines (trial) , Beijing: 2015-3-27.

[5] The national development and reform commission on climate change policy law office. China iron and steel production enterprises greenhouse gases emissions accounting methods and reporting guidelines (trial) , Beijing: 2015-3-27.

[6] The national development and reform commission on climate change policy law office. China chemical production enterprises greenhouse gases emissions accounting methods and reporting guidelines (trial) , Beijing: 2015-3-27.

[7] The national development and reform commission on climate change policy law office. China electrolytic aluminum production enterprises greenhouse gases emissions accounting methods and reporting guidelines (trial) , Beijing: 2015-3-27.

[8] The national development and reform commission on climate change policy law office. China Magnesium smelting enterprises greenhouse gases emissions accounting methods and reporting guidelines (trial) , Beijing: 2015-3-27.

[9] The national development and reform commission on climate change policy law office. China Flat glass production enterprises greenhouse gases emissions accounting methods and reporting guidelines (trial) , Beijing: 2015-3-27.

[10]The national development and reform commission on climate change policy law office. China cement manufacturers greenhouse gases emissions accounting methods and reporting guidelines (trial) , Beijing: 2015-3-27.

[11] The national development and reform commission on climate change policy law office. China Ceramic production enterprises greenhouse gases emissions accounting methods and reporting guidelines (trial) , Beijing: 2015-3-27.

[12] The national development and reform commission on climate change policy law office. China civil aviation enterprises greenhouse gases emissions accounting methods and reporting guidelines (trial) , Beijing: 2015-3-27.

[13] The national development and reform commission on climate change policy law office. China independent coking enterprises greenhouse gases emissions accounting methods and reporting guidelines (trial) , Beijing: 2015-3-27.

[14] The national development and reform commission on climate change policy law office. China coal producing enterprises greenhouse gases emissions accounting methods and reporting guidelines (trial) , Beijing: 2015-3-27.

[15] The national development and reform commission on climate change policy law office. China petrochemical enterprises greenhouse gases emissions accounting methods and reporting guidelines (trial) , Beijing: 2015-3-27.

[16] The national development and reform commission on climate change policy law office. China oil and gas production greenhouse gases emissions accounting methods and reporting guidelines (trial) , Beijing: 2015-3-27. 